\title{
The Impact of Translation Activities on the Development of African Languages in a Multilingual Society: Duramazwi reMimhanzi as a Case-study*
}

Gift Mheta, African Languages Research Institute, University of Zimbabwe, Harare,Zimbabwe(gmheta@yahoo.com)

\begin{abstract}
The article examines the impact of translation activities on the development of African languages in the multilingual Zimbabwean society. It analyses Shona musical terms created through translation processes and strategies such as borrowing, coining, compounding and derivation. Focus is on the way this ongoing term-creation is contributing to improving or hindering the development of Shona. The importance of such processes and strategies are discussed in the broader context of empowering African languages. The article also offers recommendations on how best to produce systematized terminology in music and other specialized fields.
\end{abstract}

Keywords: TRANSLATION, DEVELOPMENT OF AFRICAN LANGUAGES, MULTILINGUAL SOCIETIES, BORROWING, COINING, COMPOUNDING, DERIVATION, TERMINOLOGY, TERMINOGRAPHY

Opsomming: Die uitwerking van vertaalaktiwiteite op die ontwikkeling van Afrikatale in 'n veeltalige samelewing: Duramazwi reMimhanzi as 'n gevallestudie. Die artikel ondersoek die uitwerking van vertaalaktiwiteite op die ontwikkeling van Afrikatale in die veeltalige Zimbabwiese samelewing. Dit ontleed Sjonamusiekterme geskep deur middel van vertaalprosesse en -strategieë soos ontlening, munting, samestelling en afleiding. Die fokus is op die manier hoe voortgaande termskepping bydra tot die verbetering of belemmering van Sjona. Die belangrikeid van sulke prosesse en strategieë word bespreek in die wyer konteks van die bemagtiging van die Afrikatale. Die artikel maak ook aanbevelings hoe om op die beste manier gesistematiseerde terminologie in musiek en ander gespesialiseerde gebiede voort te bring.

Sleutelwoorde: VERTALING, ONTWIKKELING VAN AFRIKATALE, VEELTALIGE SAMELEWINGS, ONTLENING, MUNTING, SAMESTELLING, AFLEIDING, TERMINOLOGIE, TERMINOGRAFIE

* This article is based on a paper presented at the Eighth International Conference of the African Association for Lexicography, organised by the Department of Germanic and Romance Languages, University of Namibia, Windhoek, Namibia, 7-9 July 2003. 


\section{Introduction}

The first part of the article describes the general language situation in Zimbabwe that has resulted in translation and terminology development activities. The second part explores the nature of the ongoing term-creation in the music profession and shows its positive effects on Shona. The third section outlines the problems that result from the ongoing term-creation and the last part focuses on recommendations and probable solutions to the outlined problems.

\section{The language situation}

As many other African countries, Zimbabwe is a multilingual and multicultural society. However, its situation is less complex than that found elsewhere in the sub-Saharan region. The dominant languages are Shona, spoken by at least $75 \%$ and Ndebele, spoken by $10-16 \%$ of the country's estimated population of 11376 676. These two Southern Bantu languages are sometimes referred to as national languages, along with English, which is used for most official purposes. Other small but significant minority language groups, which together account for $6 \%$ of the population, are Tonga, Nambya, Venda and Kalanga in the Ndebele-speaking area, and Kalanga and Shangaan in the Shona-speaking area. In addition, there are about eight other indigenous language minorities and about five African migrant minority language groups, with Chewa/Nyanja being by far the largest, plus another five or six non-African language minorities, including English and other European languages.

Whenever there are two or more languages in a society, translation and the resultant term-creation activities become inevitable. For communication between people of different languages, translation, which is a process by which the chain of signifiers that constitutes the source language (SL) text is replaced by a chain of signifiers in the target language (TL), is always a vital activity. In order to transfer ideas across different cultures the translator's tasks involve creating rather than merely finding equivalence (Venuti 1995: 38). In other words, translation involves not only finding equivalence but also creating terms when dealing with cultural and linguistic differences between languages. Terminology, therefore, is in some cases a by-product of translation activities. This is the reason why, in this article, translation and terminology are discussed simultaneously. It is this creative component which is of particular interest to this article because it contributes to borrowing and change (Hartmann and Stork 1983: 242) and therefore allows the TL to grow in both lexical capacity and utilitarian value.

Officially, not much attention, if any, has been paid to this multilingual and multicultural situation, because the development of language, translation activities and communication is generally a neglected issue. Even up to the present, Zimbabwe has no language policy, reflecting the government's lack of 
seriousness on issues of language development. As a result, the standard of translation and the terms created through this process is low. The general attitude to translation and terminology in most sectors in Zimbabwe is rather casual and nobody seems to be desirous to appoint competent translators and terminologists.

\section{Term-creation in the music profession}

This article is based on observations made as a team member taking part in the ongoing project of compiling the Shona-Ndebele-English Dictionary of Music, Duramazwi reMimhanzi, undertaken by the African Languages Research Institute (ALRI) at the University of Zimbabwe. For this project, Shona, Ndebele and English musical terms have been collected from institutions offering music as a course or subject, and other organizations and persons involved in music. Close to 1000 Shona musical terms have been collected and entered into the musical database.

An analysis of these terms shows that many of them have been created in various tertiary institutions teaching music. In Zimbabwe, music is a well-established discipline that uses specialized terms in the analysis and teaching of sound components. As in most specialized fields, it is taught in English and some of the existing Shona terms are equivalents created from English through translation. Chimhundu (1996: 449) aptly notes:

A main trend in translation between international languages or languages of wider communication (LWCs) and indigenous languages or national official languages (NOLs) is unidirectional transfer from the LWCs as SLs to NOLs as TLs during the translation process. Both ideas and words are transferred as African societies modernize and change.

The same situation is found in the field of music. There is a unidirectional transfer of musical terms from English to Shona. This translation process often referred to as "borrowing" has resulted in the creation of many musical terms. Examples of such terms drawn from musicology are the following:

(1) aruto (alto)

bhesi (bass)

bhiti (beat)

korasi (chorus)

sopurano (soprano)

vhesi (verse)

The examples under (1) show that English terms are adopted and then adapted to the Shona phonological and morphological structures. However, term-creation does not end with borrowing but also includes other term-development processes such as coining. Examples of Shona musical terms that have been 
created by different scholars or in different institutions of music as equivalents of existing English musical concepts and terms are the following:

(2) mavambo (literally, beginning)

musoro (literally, head)

The two terms under (2) are both used to refer to the beginning of a musical piece.

(3) dziro (literally, wall (of a hut))

muviri (literally, body)

The terms under (3) are both used to refer to the basic pattern of a musical composition.

(4) chimonauswa (literally, pinnacle (of a hut))

chisuwi (literally, pinnacle (of a hut))

mabvuto (literally, climax)

makukumidzo ( literally, climax)

The terms under (4) are all used to refer to the climax of a musical composition.

(5) magumo (literally, end)

mhendero (literally, hem)

mushwe (literally, tail)

The terms under (5) are all used to refer to the end of a musical composition.

The four sets of examples are good coinages which emanate from a sound understanding of the Shona environment and language. Under (2), the example mavambo is a well-established Shona word, denoting the beginning of something. The creator of this term selected a commonly used word that any Shona speaker/hearer can easily understand and identify with. The creation of this term might also have been influenced by the analysis of the structure of folktales. A folktale, like a musical composition, has a mavambo (beginning), a muviri (middle), and a magumo (end).

The examples under (3) and (4) equate the structure of a hut with that of a musical composition which has a dziro (basic pattern) and a chisuwi/chimonauswa (climax). However, the beginning of a song is not rendered by the terms that are currently being used. With the use of terms like dziro and chisuwi/ chimonauswa, it would logically be expected to find a word like hwaro (foundation) being applied to refer to the beginning of a musical composition. This will also complete the hut imagery being applied to represent the full structure of a musical composition.

The terms musoro, muviri and mushwe under (2), (3) and (5) are drawn from animal imagery. A musical composition is thus equated to the structure of an 
animal with a head (musoro), body (muviri) and tail (mushwe). The three Shona terms respectively refer to the beginning, basic pattern and end of a musical composition. The word mushwe is also a direct translation of the English term 'tail'.

As shown under (4), the end of a musical composition is also known as mhendero, a word from the Shona lexicon referring to the hem of a type of clothing. The purpose of a hem is to make the clothing appear finished and rounded off. Any musical composition requires a logical ending, showing mhendero an appropriate term to refer to the end of a musical piece.

The above examples demonstrate that the creation of musical terms is the result of the creators' understanding of their environment and the Shona language. Any speaker/hearer of the Shona language can easily identify with the terms for they are closely linked to real and appropriate images. This alone is a way of expanding and enriching the Shona language with new terminology. However, there are problems shown up by the given examples.

\section{Problems}

The discussed examples reveal that there are many inconsistencies in the creation and use of Shona musical terms. There are too many different terms referring to the same musical concept. The end of a musical composition for instance is represented by three different terms, namely magumo, mushwe and mhendero which are drawn from divergent images.

In some interviews and term lists obtained from institutions and organizations of music, there are inconsistencies that can be noted with regard to the Shona alphabet. On some lists of Shona musical terms the English term alto is retained despite the fact that the current Shona alphabet does not include /1/. On very few Shona term lists alto is represented as aruto. The lateral $/ 1 /$ is replaced by the trill sound $/ \mathrm{r} /$. However, in most cases of speech $/ 1 /$ instead of $/ \mathrm{r} /$ is used. If the term creators in the music profession coordinate their activities, they will come up with clear-cut policies on how to deal with terms like those given under (1). Decisions on how to treat the letter 1 and letter combinations such as pr in the English term soprano can easily be reached if term-creation is well planned and coordinated. Existing speech excerpts show that most Shona speakers use /pr/ and not /pur/ when speaking and to represent the letter combination pr as pur as in the given examples is to wholly misrepresent how the Shona terms are used in actual speech.

The other problem is the inaccessibility of some Shona musical terms already created. Some of the term lists that ALRI collected from the Zimbabwe College of Music contain Ndau terms coined by the late authority on ethnomusicology in Zimbabwe, Dr D.A. Maraire. The problem with some of these is that they are easily accessible to Ndau speakers and not to users of the other Shona dialects, Korekore, Manyika, Zezuru and Karanga. Terms like mushwe and makukumidzo are examples which can easily be understood by the Ndau but not 
readily by users of the other Shona dialects. Therefore, the two terms should not be the standard musical terms for end and climax respectively. It would be better to use the terms mushwe and chimonauswa which are readily understood in most of the Shona dialects.

These examples indicate that there is a lack of uniformity of terms in the music profession which demonstrates that the term-creation that takes place is largely unplanned and uncoordinated. The chaotic situation in term-creation is not confined to the musical field but is a general problem affecting nearly all sectors of the Zimbabwean community. As noted by Chimhundu (1987: 142), term-creation is a growing phenomenon, particularly in the post-independence era in Zimbabwe. It is proliferating in business, central and local government, commerce, industry, mining, agriculture, broadcasting, education and other spheres of life. If this continues unchecked, it will eventually result in an undesirable terminological "flood". In other words, the result will be an influx of terms created outside the standards and principles that govern terminology development.

A situation whereby every institution has its own set of terms does not promote language development. As noted by Karl Marx, development comes through the effective control of resources, including language. In other words, language development should be well-ordered and -planned. He states that "language would be one of the things that in time would be taken under human control by the victorious proletariat" (quoted by Grinev 1987: 49). But the big question is who has to control language development in a country.

\section{Recommendations}

If the music profession is to produce terminological work that will promote the development of Shona, committees responsible for the development of musical terms should be formed. These committees should be established in the four main provinces of Zimbabwe namely Mashonaland, Matabeleland, Manicaland and the Midlands. The committees should comprise lecturers, academics and personnel from institutions and organizations dealing with musical terms. These provincial committees should collect Shona musical terms created in the areas they represent.

The chairpersons of the provincial committees should form the national board for the development of Shona musical terms. The board should be responsible for analysing the terms created so far in the music profession. To give credibility to the decisions of the national board, it should work closely with other committees, boards, institutions and organizations that have the development of indigenous languages at heart. The Shona Language Committee and ALRI are examples of groups with which such a national board for the development of Shona musical terms can cooperate in the implementation of the basic principles of terminological activities in the music profession. This recommendation, if implemented, should ensure uniformity in the creation and use of musical terms. 
For the above recommendations to be effectively implemented, however, it is necessary for the Zimbabwean government to be actively involved by providing financial assistance. The above recommended committees need financial support from the government for them to effectively pursue the objective of systematically creating and storing musical terms. Terminological management requires adequate resources like buildings, research equipment and well-trained personnel. The result would be the implementation of the suggested recommendations not only for the music domain but also for other fields using specialized terms.

The government should also go a step further by forming a national unit for terminology development. Such a unit should be responsible for the ultimate documentation, standardization and publishing of term lists covering not only the music domain but also various other fields. The main objective of such a unit should be to reduce ambiguity and misunderstandings and thereby improving the exactness of technical communication. The proposed unit should deal with terminology not only of music, but also meteorology, basic health, HIV / AIDS, commerce, finance, banking, basic agriculture, information technology and other specialized fields. It should work in collaboration with linguists and specialists in these various subject fields. The unit should start with the two main indigenous languages in Zimbabwe, Shona and Ndebele, and then with time involve the recognized minority languages.

Another positive step would be to introduce tertiary training in the theory and principles of terminology. Currently, such training receives little attention. At the University of Zimbabwe in Harare, for instance, it is only taught as part of the translation and lexicography courses and as such does not receive a fair coverage. Both these courses are optional and consequently some graduates who have studied African languages have no knowledge of terminology. Furthermore, these courses are covered by only one module and the obvious result is that very little attention is given to terminological theory and principles. As a solution to this problem, it would be better for the Department of African Languages and Literature at the University of Zimbabwe and similar departments at various tertiary institutions in Zimbabwe to follow the example set by the Department of African Languages and Literature at the Midlands State University in Gweru where translation and lexicography are taught as different modules, the former in the second and the latter in the final year. The teaching of these two courses at different levels ensures that are they taught over a twoyear period, hence giving more time for terminology, which is also included in the two modules. In addition, these courses are compulsory. If all tertiary institutions would follow suit, it would mean more students will receive training in terminology. However, teaching terminology as an independent subject will ensure training of terminologists and terminographers of a better quality. This is exactly what is happening in South Africa which in 2003 introduced a module on the practice and principles of terminology and terminography as part of the M.A. in the Department of African Languages at the University of Pretoria. 
For quality terminological work to be realised in Zimbabwe, the same road as that taken in South Africa should be followed.

Terminological problems in the music profession and other specialized fields are not without solutions. It will only take patience and effort from the concerned stakeholders in implementing and developing the above recommendations. Effective implementation and development of these suggestions will in future enhance the communicative power of the indigenous languages of Zimbabwe.

\section{References}

Chimhundu, H. 1987. Pragmatic Translation and Language Elaboration. Pongweni, J.C.A. and J. Thondhlana (Eds.). 1990. LASU Conference Proceedings 1987: 140-152. Harare: LASU.

Chimhundu, H. 1996. Translation in African LLDs and Communication for Development. Malone, J.L. (Ed.). 1996. XIV World Congress of the Fédération Internationale des Traducteurs (FIT) Proceedings, Melbourne, Australia, 9-16 February 1996. Melbourne: The Australian Institute of Interpreters and Translators (AUSIT).

Grinev, S.V. 1987. Theoretical Foundations of Russian Terminology Work: Peculiarities and Perspectives. Grinev, S.V. (Ed.). 1987. Applications and Implications of Current LSP Research. Volume 1: 49-56. Bergen: Fagbokforlaget.

Hartmann, R.K.K. and F.C. Stork. 1988. Dictionary of Language and Linguistics. London: Applied Science Publishers.

Venuti, L. 1995. The Translator's Invisibility. London: Routledge. 